\title{
Quality of mussels cultivated and commercialized in Ubatuba, SP, Brazil - monitoration Bacillus cereus and Staphylococcus aureus growth after post-harvest processing
}

\author{
Tratamento térmico de mexilhões Perna perna como forma de assegurar a qualidade - \\ avaliação do crescimento de Bacillus cereus e de Staphylococcus aureus
}

\author{
Eduardo Oliveira SALÁN ${ }^{1 \star}$, Juliana Antunes GALVÃOํㅗㄹ Érika Fabiane FURLAN², \\ Ernani PORTO${ }^{1}$, Cláudio Rosa GALLO ${ }^{1}$, Marília OETTERER ${ }^{1}$
}

\begin{abstract}
Aiming at improving the quality of Perna perna mussels cultivated and commercialized in Ubatuba, SP, Brazil, the growth and elimination of Staphylococcus aureus and Bacillus cereus artificially inoculated in mussels were studied. The inoculation was carried out in "in natura" and pre-cooked mussels for $30 \mathrm{~min}$, and after that the mussels were kept for 10 hours at room temperature $\left(25 \pm 1{ }^{\circ} \mathrm{C}\right)$ and under refrigeration $\left(7 \pm 1^{\circ} \mathrm{C}\right)$. Six thermal treatments were evaluated: three using steam $(5,10$ and 15 minutes $)$ and three in boiling water $(5,10$ and 15 minutes), in order to find the best time/temperature binomial to provide pathogenic control. Yield and physical-chemical and sensory characteristics were evaluated. All thermal treatments were efficient to eliminate microorganisms in 2 logarithmic cycles. However, the boiling water treatments presented better results than the steam treatments. The physical-chemical and sensory analyses did not show statistical differences among the thermal treatments studied. The best performances were reached in the shortest times of heat exposure. Overall, the treatments in boiling water presented better results than the steam treatments.
\end{abstract}

Keywords: microorganisms; mussel farming; processing.

\section{Resumo}

Buscando a qualidade do mexilhão Perna perna cultivado e comercializado no município de Ubatuba, SP, foram estudados o crescimento e o controle de Staphylococcus aureus e Bacillus cereus inoculados artificialmente em mexilhões in natura e pré-cozidos, mantidos por 10 horas à temperatura ambiente $\left(25 \pm 1^{\circ} \mathrm{C}\right)$ e sob refrigeração $\left(7 \pm 1^{\circ} \mathrm{C}\right)$. Foram estabelecidos seis tipos de tratamentos térmicos, sendo três sob vapor (5, 10 e 15 minutos) e três por imersão em água (5, 10 e 15 minutos), buscando estabelecer o binômio que proporcionasse a diminuição da contagem microbiana. Posteriormente, foram avaliados o rendimento, os aspectos físico-químicos e sensoriais. Todos os tratamentos térmicos foram eficientes, pois reduziram a contagem microbiana em pelo menos 2 ciclos logarítmicos. Porém, o tratamento térmico por imersão em água com ebulição apresentou resultados melhores que os tratamentos a vapor. As análises físico-químicas e sensoriais não mostraram diferença estatística entre os tratamentos térmicos estudados. Os melhores desempenhos foram alcançados nos menores tempos de exposição ao calor, e os tratamentos em água com ebulição apresentaram resultados mais satisfatórios que os tratamentos a vapor.

Palavras-chave: microrganismos; mitilicultura; beneficiamento.

\section{Introduction}

Aquaculture has been growing rapidly over the last decades, with an average $10 \%$ growth a year since 1984 (FAO, 2005). Mollusk farming accounts for $24 \%$ of the total international aquacultural production and mussels represent about $13.3 \%$ of this production (OSTRENSKY; BORGHETTI; PEDINI, 2000; STREIT et al., 2002).

In Brazil, marine aquaculture is represented basically by the farming of crustaceans and mollusks. Brazilian production of mollusks is about 6,690 tons a year, which represents $48 \%$ of all the mussels produced in Latin America (SUBASINGHE et al., 2001). According to Borghetti and Ostrensky (2000), Perna perna mussels, two species of oysters and one of scallops are produced in Brazil.
Mussel farming is one of the most productive activities of aquaculture, reaching up to 30 tons of meat per hectare/year, which represents the highest amount obtained with a modality that is not submitted to artificial feeding. Besides several favorable biological aspects, other factors such as the lower cost of installations, ease of handling, and localization of the culture in the sea contributed towards the international expansion of this activity (GELLI et al., 1998; PEREIRA et al., 2005).

Due to their distribution in the seashore and estuary, mollusks are constantly submitted to sewage pollution, especially near large urban centers. The presence of bacteria and pathogenic virus are the main dangers associated to pollution, which becomes a Public Health problem, affecting the reputation of the

\footnotetext{
Recebido para publicação em 27/9/2006

Aceito para publicação em 17/12/2007 (001867)

Departamento de Agroindústria, Alimentos e Nutrição, Escola Superior de Agricultura Luiz de Queiroz - ESALQ, Universidade de São Paulo - USP, Av. Pádua Dias, 11 ,

CP 9, CEP 13418-900, Piracicaba - SP, Brasil, E-mail: esalan@kerrygroup.com

2 Unidade Laboratorial de Referência em Tecnologia do Pescado, Centro APTA do Pescado Marinho, Instituto de Pesca, Av. Bartolomeu de Gusmão, 192, Ponta da Praia,

CEP 11030-906, Santos - SP, Brasil

${ }^{*}$ A quem a correspondência deve ser enviada
} 
food and the population. The consumption of fresh or slightlycooked mollusks makes this problem worse (RODRIGUES, 1999; RODRIGUES-ARIZA et al., 1992).

Both B. cereus and S. aureus are frequently involved in the outbreak of food-borne diseases and are consequently isolated in human beings. According to data from the United States Department of Agriculture (USDA), from 1993 to 1997, 14 outbreaks and 691 cases, and 41 outbreak and 1413 cases (one death) caused by B. cereus and S. aureus, respectively, were reported in the United States (LANCIOTTI et al., 2001).

The potential risk of developing a food-borne disease caused by $B$. cereus and $S$. aureus through the consumption of mussels cultivated in Ubatuba, SP, Brazil, has been identified (GALVÃO et al., 2006).

The storage of mollusks is limited if they are commercialized in their natural condition; the valves occupy a lot of space, making storage difficult. One of the advantages of processing this product is the possibility of presenting it in a more attractive condition than the traditional one, as well as allowing storage for longer periods, making consumption more flexible (BEIRÃO et al., 2000).

Thermal processing is the key area in mussel processing in order to obtain the required sensory properties. It also inactivates bacteria and enzymes with the objective of producing a safer and more stable food. An adequate shelf life is essential for the demand in the exporting market, and for the expansion of the domestic market (SKIPNES et al., 2002; WOOD, 1979).

Fish is consumed because of its higher nutritional value and typical and varied taste. These characteristics must be qualitatively and quantitatively present, not only in the processed food, such as in surimi-based products, but also in the original foods, such as farmed fish and mussels, which may have a milder taste than those in their wild stage (HAARD, 1992).

The main purpose of the present investigation was to verify the growth of Bacillus cereus and Staphylococcus aureus inoculated in fresh and pre-cooked mussel samples stored for a period of 10 hours at room temperature $\left(25 \pm 1^{\circ} \mathrm{C}\right)$ and under refrigeration $\left(7 \pm 1{ }^{\circ} \mathrm{C}\right)$ and to establish the time-temperature binomial to control these microorganisms through six different thermal treatments, besides evaluating the effect of these treatments on the physical, chemical and sensory characteristics of this mollusk.

\section{Materials and methods}

\subsection{Sample collection}

Perna perna mussel samples were collected from a commercial farm located in Costão da Praia do Cedro, in Ubatuba, SP ( $23^{\circ} 33^{\prime} 45.5^{\prime \prime}$ S, $\left.45^{\circ} 09^{\prime} 32.9^{\prime \prime} \mathrm{W}\right)$, from November 2003 to March 2004.

The mussels collected were submitted to cleaning, in order to remove barnacles and parasites. They were then washed with sea water, packed in raffia bags, placed in Styrofoam boxes with ice in a ratio of 1:1, with no direct contact with the ice, to avoid the death of the mussels.

\subsection{Growth of S. aureus and B. cereus}

\section{Inoculum Preparation}

IZ 1974 and CCT 0198 strains were used as Staphylococcus aureus and Bacillus cereus inoculums, respectively. Both were kept at room temperature in tubes with inclined nutrient agar (NA) (Merck).

After reactivation in Brain Heart Infusion broth (BHI) (Oxoid), for S. aureus, and nutrient broth (NB) (Merck), for $B$. cereus, for 24 hours, at $36 \pm 1{ }^{\circ} \mathrm{C}$, the growth curve was determined, where the period necessary to obtain an inoculum with $10^{8} \mathrm{CFU} \mathrm{g}^{-1}$ was determined.

\section{Sample and inoculum preparation}

The mussel shells were washed under running water with the aid of a sterile brush and distributed in paper towels to remove the washing water (VANDERZANT; SPLITTSTOESSER, 1992). The batch was separated into two sub-batches, one for analysis in the natural condition and the other for analysis of the cooked and shell-less material.

After cleaning, one of the sub-batches was pre-cooked in a water bath up to boiling temperature, for about 5 minutes, until the shells opened. Then, they were immersed in water and ice in order to cool rapidly and reach an internal temperature of $10{ }^{\circ} \mathrm{C}$ to be removed from the shells.

After a 24-hours reactivation of the cultures, $1 \mathrm{~mL}$ was inoculated in $100 \mathrm{~mL} \mathrm{BHI}$ and incubated for 6 hours at $37^{\circ} \mathrm{C}$. Then, an aliquot of $1 \mathrm{~mL}$ was suspended into $10 \mathrm{~L}$ of a $0.7 \%$ saline solution, where $1 \mathrm{~kg}$ of fresh or shell-less cooked mussels was inoculated for 30 minutes. After this period, mussels were drained for 15 minutes and placed in sterile containers.

The two treatments were divided once again into three samples: one for immediate analysis; one stored under refrigeration $\left(7 \pm 1{ }^{\circ} \mathrm{C}\right)$ and the other stored at room temperature $\left(25 \pm 1^{\circ} \mathrm{C}\right)$ for 10 hours.

\section{Microbiological analysis}

The fresh mussels were forced open around the byssus area with the aid of a knife, the water was drained, and the meat was completely removed and placed in a sterile beaker (VANDERZANT; SPLITTSTOESSER, 1992).

For the presumptive count of both microorganisms, we used the direct plate count method, in accordance with Vanderzant; Splittstoesser (VANDERZANT; SPLITTSTOESSER, 1992), in which $1 \mathrm{~mL}(0.3,0.3,0.3$ and $0.1 \mathrm{~mL})$ of the dilution of $10^{-3}$ and $0.1 \mathrm{~mL}$ of the dilutions of $10^{-4}$ and $10^{-5}$ were inoculated in the fresh mussels, and $1 \mathrm{~mL}(0.3,0.3,0.3$ and $0.1 \mathrm{~mL})$ of the dilution of $10^{-5}$ and $0.1 \mathrm{~mL}$ of the dilutions of $10^{-6}$ and $10^{-7}$ were inoculated in the cooked mussels.

\section{Bacillus cereus count}

Inoculums were spread in duplicates with a Drigalsky spreader on Petri dishes with Mannitol Yolk Polymyxin Agar 
(MYPA) (Merck), previously added of yolk emulsion (Oxoid) and Polymyxin B (Oxoid), until excess liquid was absorbed.

After drying, the dishes were inverted and incubated at $36 \pm 1{ }^{\circ} \mathrm{C}$ for 20 to 24 hours. After this period, typical colonies (large, with no specific form, pink, surrounded by an opacity zone) were selected for confirmative Gram and catalase tests. Some typical colonies were inoculated in a BHI broth and incubated at $36 \pm 1{ }^{\circ} \mathrm{C}$, for 24 hours, in order to carry out other identification tests: motility, nitrate reduction, tyrosine decomposition, rhizoid growth and Voges-Proskauer (VP) tests.

\section{Staphylococcus aureus count}

Inoculums were spread in duplicates with a Drigalsky spreader on Petri dishes with Baird-Parker Agar (BPA) (Merck), previously added of yolk tellurite (Oxoid), until excess liquid was absorbed. After drying, the dishes were inverted and incubated at $36 \pm 1{ }^{\circ} \mathrm{C}$, for 48 hours. After this period, typical colonies (black, bright, circular, plain, convex, and surrounded by a transparent halo) were selected for confirmative Gram, catalase and coagulase tests.

\subsection{Mussel thermal treatments}

After hygienization with the aid of a sterile brush, the mussel batch was separated into 6 samples ( $1 \mathrm{~kg}$ each), which were submitted to the following cooking times: 5,10 and 15 minutes in steam, and 5, 10 and 15 minutes in a water bath. For cooking, the mussels were placed in wire baskets $(20 \mathrm{~cm}$ top diameter $\times 16.5 \mathrm{~cm}$ bottom diameter $\times 10 \mathrm{~cm}$ height), suspended in a lidded stainless steel container $(24.5 \mathrm{~cm}$ diameter $\mathrm{X}$ $14 \mathrm{~cm}$ height).

The cooking temperature was monitored by a group of thermocouples with 5 calibrated sensors. They were distributed as follows: at the bottom of the recipient, in the middle, on the surface, and in the center of the mussel mass. The fifth thermocouple was placed in the cooling recipient, where the mussels were immersed in water with ice at the rate of 3:1, until their internal temperature reached $10{ }^{\circ} \mathrm{C}$.

\section{Microbiological analysis}

After cooking, the mussels were removed from their shells and placed in a sterile recipient. Microbiological analysis was carried out as described for the fresh and pre-cooked mussel analysis.

\section{Physical-chemical analysis}

Moisture, protein, lipids, carbohydrates and ash analyses were carried out according to the Association of Official Analytical Chemists (A.O.A.C., 1995).

A Digimed digital potentiometer was used to determine the $\mathrm{pH}$. A sample (meat + intravalvar liquid) triturated with water, at the rate of 1:1, was measured.

\section{Yield}

Yield calculation was carried out to verify possible losses in mussel yield depending on the cooking period. Before each treatment, the fresh samples were weighed and their shells were removed. After that, the meat and shells with residues were weighed separately. The yield was obtained according to the following formulas (Equations 1 and 2):

Total weight $($ in $\%)=\frac{\text { cooked meat weight }}{\text { fresh mussel weight }} \times 100$

Edible part $($ in $\%)=\frac{\text { cooked meat weight }}{(\text { fresh mussel weight }- \text { shell weight })} \times 100$

Biometry constituted in the measurement of the valves of 100 individuals from each collection with the help of a pachymeter.

\section{Sensory analysis}

An ordering test was carried out using 4 samples (5 and 10 minutes in water, and 5 and 10 minutes in steam), which were presented to panelists to be organized in an increasing order, according to their general appreciation of the product. The team was formed by 50 untrained panelists who, nevertheless, were acquainted with the product.

The results were calculated by the sum of the ordering of each sample and statistically evaluated by Friedman's test, using the data from Newell; MacFarlane's table (A.O.A.C., 1995).

\subsection{Statistical Analysis}

The results of the physical-chemical analyses were submitted to analysis of variance using the SAS software (SAS INSTITUTE, 1999). Means were compared by the Tukey test, adopting a significance level of $5 \%$.

\section{Results and discussion}

\subsection{Inoculation}

Table 1 presents the results of the growth of Staphylococcus aureus inoculated in fresh and pre-cooked mussels kept at room temperature $\left(25 \pm 1^{\circ} \mathrm{C}\right)$ or under refrigeration $\left(7 \pm 1^{\circ} \mathrm{C}\right)$.

As can be observed in Table 1, microbial growth occurred both in fresh or pre-cooked mussels kept at room temperature or under refrigeration. The largest growth of S. aureus was observed in cooked mussels after 10 hours storage at room temperature, when counts of 5.3 to $6.1 \times 10^{7} \mathrm{CFU} \mathrm{g}^{-1}$ were observed, with an increase of 3 logarithmic cycles. This is an important aspect, once $S$. aureus is related to food-borne diseases. It is well known that a density of $10^{6}-10^{8} \mathrm{CFU} \mathrm{g}^{-1}$ is associated to enterotoxin production in a toxic level (SILVA, 2000).

According to Ayulo, Machado and Scussel (1994), fish and mussels produced and commercialized in the state of Santa Catarina were positive for S. aureus in $20 \%$ of the analyzed samples and also $60 \%$ of the bivalve samples presented S. aureus, but only 9 out of 109 strains of $S$. aureus produced enteroxin, including enteroxins A (4), D (1) and B (4). 
A different behavior was observed for B. cereus inoculated in fresh and pre-cooked mussels kept at room temperature $\left(25 \pm 1^{\circ} \mathrm{C}\right)$ and under refrigeration $\left(7 \pm 1^{\circ} \mathrm{C}\right)$ (Table 2$)$. In fresh mussels kept at room temperature, a growth of 1 logarithmic cycle was observed 10 hours after inoculation, whereas for cooked mussels kept at room temperature $\left(25 \pm 1^{\circ} \mathrm{C}\right)$ a large microbial growth of $10^{4}$ to $10^{8}$ was observed.

Johnson, Nelson and Busta (1983) observed that in a Trypticase Soy broth, B. cereus growth was observed between 15 and $50{ }^{\circ} \mathrm{C}$, being optimal between 35 to $40{ }^{\circ} \mathrm{C}$. Mead et al. (1999) presented the possibility of growth at 4 to $50{ }^{\circ} \mathrm{C}$ for this microorganism. This is an important data related to spore production, since from $10^{7}$ to $10^{8}$ cells $^{-1}$ of food are needed for the incidence of food-borne gastroenteritis (FORSYTHE, 2002).

Ola and Oladipo (2004) have also studied the storage period of the cassava croaker (Pseudotholitus senegalensis) in ice and at room temperature, and observed that the total count of microorganisms increased from $10^{3}$ to $10^{6} \mathrm{CFU} \mathrm{g}^{-1}$ after 12 hours storage, resulting in rejection by consumers after sensory analysis. In this study, it was also observed that Bacillus was the most important contribution to the increase in counts during storage. On the

Table 1. Counts of Staphylococcus aureus inoculated in fresh and precooked mussels, after 10 hours storage at room temperature or under refrigeration.

\begin{tabular}{lccc}
\hline & Initial $^{1}$ & \multicolumn{2}{c}{ After 10 hours storage } \\
\cline { 2 - 4 } & & $\begin{array}{c}\text { Room temperature } \\
\left(25 \pm 1{ }^{\circ} \mathrm{C}\right)\end{array}$ & $\begin{array}{c}\text { Refrigeration } \\
\left(7 \pm 1{ }^{\circ} \mathrm{C}\right)\end{array}$ \\
\hline Fresh mussels \\
\hline Sample 1 & $5.0 \times 10^{3}$ & $2.5 \times 10^{5}$ & $1.0 \times 10^{4}$ \\
Sample 2 & $6.0 \times 10^{3}$ & $4.0 \times 10^{5}$ & $2.0 \times 10^{4}$ \\
Sample 3 & $3.0 \times 10^{3}$ & $3.0 \times 10^{5}$ & $1.0 \times 10^{4}$ \\
Mean & $4.6 \times 10^{3}$ & $3.2 \times 10^{5}$ & $1.3 \times 10^{4}$ \\
\hline \multicolumn{4}{c}{ Cooked mussels ${ }^{1}$} \\
\hline Sample 1 & $5.6 \times 10^{4}$ & $5.3 \times 10^{7}$ & $1.7 \times 10^{5}$ \\
Sample 2 & $6.0 \times 10^{4}$ & $6.1 \times 10^{7}$ & $1.3 \times 10^{5}$ \\
Sample 3 & $6.4 \times 10^{4}$ & $5.8 \times 10^{7}$ & $1.7 \times 10^{5}$ \\
Mean & $6.0 \times 10^{4}$ & $5.7 \times 10^{7}$ & $1.6 \times 10^{5}$ \\
\hline
\end{tabular}

${ }^{1}$ Mean of duplicates, expressed in $\mathrm{CFU} \mathrm{g}{ }^{-1}$ of meat.

Table 2. Bacillus cereus inoculated in fresh and pre-cooked mussels, after 10 hours storage at room temperature and under refrigeration.

\begin{tabular}{lccc}
\hline & Initial & \multicolumn{2}{c}{ After 10 hours storage } \\
\cline { 2 - 4 } & & $\begin{array}{c}\text { Room temperature } \\
\left(25 \pm 1{ }^{\circ} \mathrm{C}\right)\end{array}$ & $\begin{array}{c}\text { Refrigeration } \\
\left(7 \pm 1{ }^{\circ} \mathrm{C}\right)\end{array}$ \\
\hline \multicolumn{4}{c}{ Fresh mussels ${ }^{1}$} \\
\hline Sample 1 & $4.0 \times 10^{3}$ & $3.1 \times 10^{4}$ & $4.0 \times 10^{3}$ \\
Sample 2 & $6.0 \times 10^{3}$ & $3.0 \times 10^{4}$ & $5.0 \times 10^{3}$ \\
Sample 3 & $5.0 \times 10^{3}$ & $3.1 \times 10^{4}$ & $6.0 \times 10^{3}$ \\
Mean & $5.0 \times 10^{3}$ & $3.1 \times 10^{4}$ & $5.0 \times 10^{3}$ \\
\hline \multicolumn{4}{c}{ Cooked mussels ${ }^{1}$} \\
\hline Sample 1 & $2.0 \times 10^{4}$ & $6.6 \times 10^{8}$ \\
Sample 2 & $2.1 \times 10^{4}$ & $4.5 \times 10^{8}$ & $5.3 \times 10^{4}$ \\
Sample 3 & $1.8 \times 10^{4}$ & $7.0 \times 10^{8}$ & $5.3 \times 10^{4}$ \\
Mean & $1.9 \times 10^{4}$ & $6.0 \times 10^{8}$ & $5.6 \times 10^{4}$ \\
\hline
\end{tabular}

${ }^{1}$ Mean of duplicates, expressed in $\mathrm{CFU} \mathrm{g}^{-1}$ of meat. other hand, when stored under refrigeration, Bacillus presented a slight decrease after 20 days storage.

Rawles et al. (1995)., studying the growth of Listeria monocytogenes in cooked blue crab meat under refrigeration, obtained 7 logarithmic cycles at the end of 21 days of storage at $5{ }^{\circ} \mathrm{C}$. This growth became more intense after the $10^{\text {th }}$ day of storage. Also, Reily and Hackney (1985) observed the growth of Vibrio cholerae in inoculation-infected oysters kept for 21 days under refrigerated storage $\left( \pm 7^{\circ} \mathrm{C}\right)$ and obtained a reduction of 3 logarithmic cycles in the first 7 days of storage, which remained unaltered in the next 14 days.

In this paper, refrigeration proved to be an efficient process in controlling the growth of both microorganisms and shows the importance of refrigerating this product, mostly after thermal treatment and without the valve, when the product can be easily infected.

Inoculation was more efficient in pre-cooked mussels than in fresh mussels, which shows the importance of the shell in mussel protection against microbial infection.

According to epidemiological data, between 1986 and 1995 , bacterial pathogens were referred to as the main causes of several outbreaks in Taiwan, Republic of China (555 out of 852 outbreaks, $65 \%$ ), being S. aureus (169 out of 555 outbreaks, $30 \%$ ) and B. cereus (104 out of 555 outbreaks, 18\%) two of the main causative agents of these outbreaks (PAN et al., 1997).

\subsection{Thermal treatment}

Figure 1 shows the average temperatures reached at the end of the different cooking periods.

All thermal treatments reached temperatures above $60{ }^{\circ} \mathrm{C}$, the differences registered in temperature ranges among the thermocouples in the same system did not exceed $10^{\circ} \mathrm{C}$, except in steam cooking for 5 minutes. This suggests a uniform distribution of the heat in the conditions of the experiment. In thermal treatment studies carried out by Antoniolli (1999), there were no variations in heat distribution, as observed in our study.

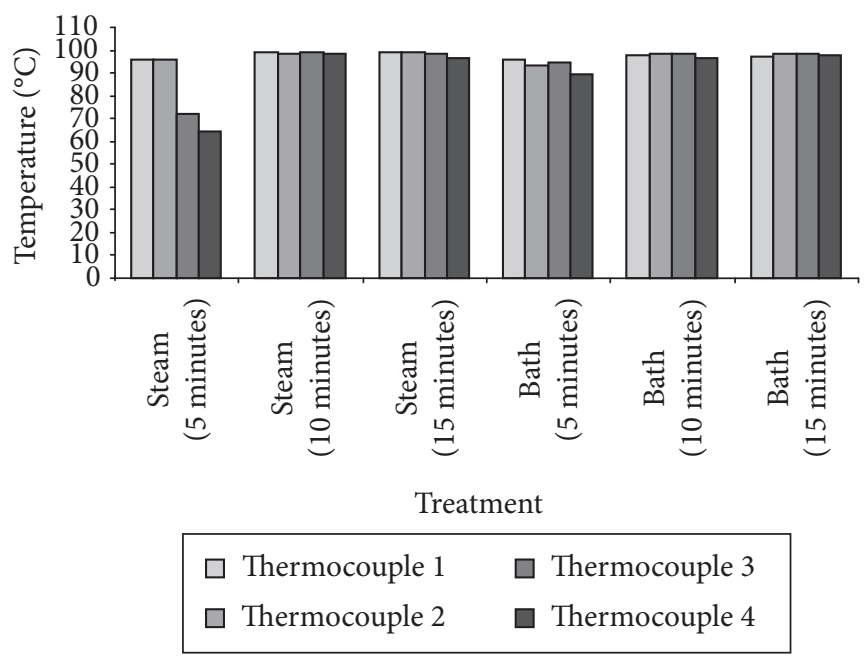

Figure 1. Average temperatures measured by the thermocouples after different cooking periods. 
According to Pigott and Tucker (1990), pathogenic microorganisms are destroyed at temperatures under $100^{\circ} \mathrm{C}$, and the effect of increasing the internal food temperature to $66^{\circ} \mathrm{C}$ is enough to make the food safe.

This evidence can be observed in Figure 2, where the values of the Most Probable Number (MPN) for Staphylococcus aureus and Bacillus cereus in all treatments applied are presented. Both microorganisms presented similar behavior, and were reduced by at least 2 logarithmic cycles in all treatments. It is evident that the thermal treatments applied were efficient to decrease the microorganisms inoculated considerably. It was also noticed that treatments with boiling water were more efficient in microbial reduction, if compared to treatments with steam.

Antoniolli (1999), studying the shelf life of processed and refrigerated Perna perna mussels, used different cooking periods, from 15 to 30 minutes, obtaining final temperatures vary-
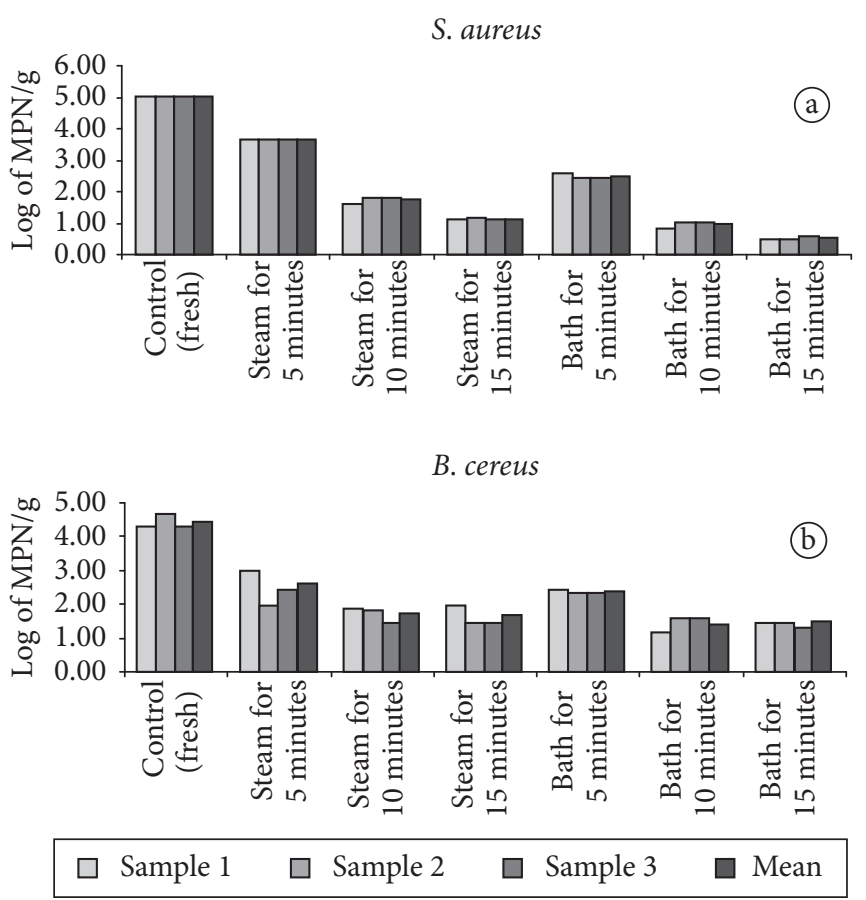

Figure 2. Staphylococcus aureus and Bacillus cereus inoculated in mussel samples and submitted to different thermal treatments. ing from 80 to $96^{\circ} \mathrm{C}$, and observed that all thermal treatments applied were satisfactory to decrease microorganism counts. Also, Chai et al. (1991) studied the thermal processing of oysters and suggested the treatment at $75-76^{\circ} \mathrm{C}$, for 8 minutes, aiming a product of better quality.

Another means of reducing microorganisms was studied by Juneia, Marmer and Eblen (1999), who showed that the addition of $\mathrm{NaCl}$ protects the pathogenic agent, in this case, E. coli O157:H7, against the lethal effect of heat. Kotrola and Conner (2002)showed that the survival of E. coli in poultry meat was significantly increased (longer period of decimal reduction) by the use of additive elements, such as sodium lactate, sodium chloride and polyphosphates, in the preparation of turkey meat. In all cases, the percentage of water was reduced, as well as the water mobility in the environment.

Ama, Hamdy and Toledo (1994) studied the effects of temperature and $\mathrm{pH}$ in the inactivation of $\mathrm{V}$. vulnificus and observed that for higher initial counts of microorganisms $\left(\sim 10^{7}\right.$ per $\mathrm{mL}$ or $\mathrm{g}$ ), the thermal treatments are not effective. This evidence is important because, despite the fact that thermal treatment is effective in eliminating microorganisms, it cannot be used for this purpose when the raw material is of poor quality.

\subsection{Centesimal composition and $p H$}

The results obtained for the centesimal composition and $\mathrm{pH}$ of fresh and cooked mussels (different thermal treatments) are presented in Table 3.

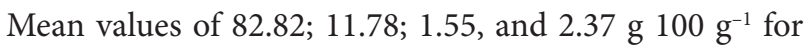
moisture, protein, lipids and ash, respectively, were obtained for the fresh mussels. These data are in accordance with several food composition tables, such as that from the Santa Catarina Aquaculture Association (ACAQ, 2005), which presents values

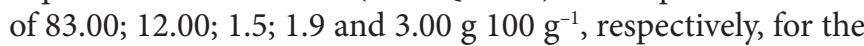
same shellfish studied in this research, and the same parameters; and Franco's table (2004), which presents values of 14.40 and

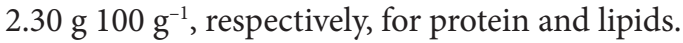

Pedrosa and Cozzolino (2001) evaluated the centesimal composition of fresh mussels (Anomalocardia brasiliana), and

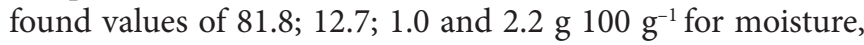
protein, lipids and ash, respectively. Also, Bindu et al. (2002) observed the nutritional composition of fresh Perna viridis mus-

Table 3. Centesimal composition and $\mathrm{pH}$ of the mussels submitted to different thermal treatments.

\begin{tabular}{|c|c|c|c|c|c|c|}
\hline \multirow[t]{2}{*}{ Thermal Treatment ${ }^{1,2}$} & Moisture & Protein & Lipids & Ash & Carbohydrates & $\mathrm{pH}$ \\
\hline & \multicolumn{6}{|c|}{${\mathrm{g} 100 \mathrm{~g}^{-1}}$} \\
\hline Control (Fresh) & $82.82^{2^{3}}$ & $11.78^{\mathrm{a}}$ & $1.55^{\mathrm{a}}$ & $2.37^{\mathrm{a}}$ & $1.98^{\mathrm{a}}$ & $6.46^{\mathrm{a}}$ \\
\hline \multicolumn{7}{|l|}{ Steam } \\
\hline 5 minutes & $79.85^{\mathrm{a}}$ & $15.01^{\mathrm{a}}$ & $1.79^{\mathrm{a}}$ & $2.03^{\mathrm{a}}$ & $1.32^{\mathrm{a}}$ & $6.87^{\mathrm{a}}$ \\
\hline 10 minutes & $75.57^{\mathrm{a}}$ & $17.52^{\mathrm{a}}$ & $2.33^{\mathrm{a}}$ & $2.05^{\mathrm{a}}$ & $2.53^{\mathrm{a}}$ & $6.97^{\mathrm{a}}$ \\
\hline 15 minutes & $75.13^{\mathrm{a}}$ & $17.34^{\mathrm{a}}$ & $2.57^{\mathrm{a}}$ & $2.01^{\mathrm{a}}$ & $2.95^{\mathrm{a}}$ & $7.07^{\mathrm{a}}$ \\
\hline 10 minutes & $77.11^{\mathrm{a}}$ & $16.80^{\mathrm{a}}$ & $2.61^{\mathrm{a}}$ & $1.61^{\mathrm{a}}$ & $1.87^{\mathrm{a}}$ & $7.08^{\mathrm{a}}$ \\
\hline 15 minutes & $76.23^{\mathrm{a}}$ & $16.59^{\mathrm{a}}$ & $2.81^{\mathrm{a}}$ & $1.56^{\mathrm{a}}$ & $2.81^{\mathrm{a}}$ & $7.11^{\mathrm{a}}$ \\
\hline
\end{tabular}

${ }^{1}$ Mean of triplicates; ${ }^{2}$ period measured after boiling point; ${ }^{3}$ means followed by the same letters in columns are not statistically different $(\mathrm{p}<0.05)$. 


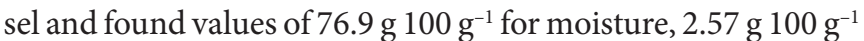

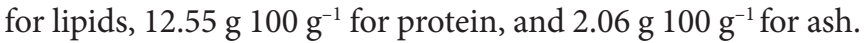
These values are close to the ones found in this study.

Different values from those found in this research were presented by Tavares et al. (1998), who evaluated the variation of the composition of Perna perna mussels along the year in Ubatuba/SP and obtained lower values for moisture $(72.12 \mathrm{~g}$ $\left.100 \mathrm{~g}^{-1}\right)$, and higher values for protein $\left(20.5 \mathrm{~g} 100 \mathrm{~g}^{-1}\right)$ and lipids

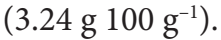

The nutritional composition of green crab claws (Carcinus maenus) was studied by Skonberg and Perkins (2002). No differences were observed in the centesimal composition of the raw or cooked claws after twelve minutes in steam, as observed in our research for mussels.

Gokoglu, Yerlikaya and Cengiz (2004), studying the effects of different cooking methods on the centesimal composition and the mineral content of rainbow trout (Oncorhynchus mykiss), observed that trout cooked in boiling water for 5 minutes. did not differ significantly in their protein and fat content, but presented reduced values for moisture and ash.

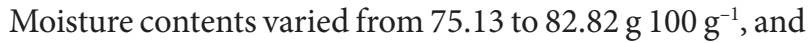
the more intense the thermal treatment, the lower the moisture values. Similar values were found in Schramm's (1993) research,

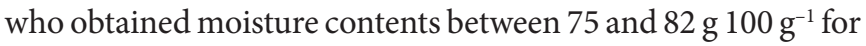
mussels pre-cooked in boiling water for 5 minutes, and Oetterer

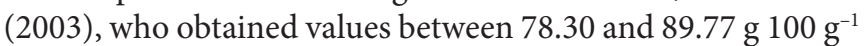
for fresh mussels.

The protein contents found in this work ranged from

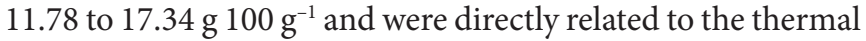
treatment applied. Higher protein contents were observed in the treatments with a longer period of exposure to high temperatures and in the steam treatments. Our data were higher than

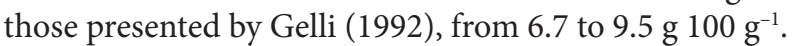

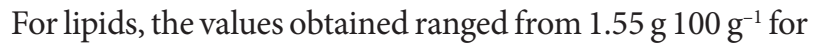

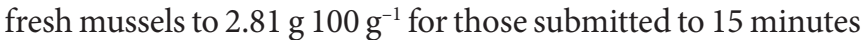
in boiling water. In a study by Ackman (1999), shellfish lipids

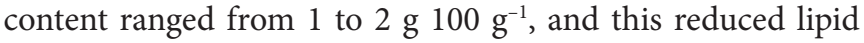
content was related to the storage of energy in the glycogenic form by bivalves.

The $\mathrm{pH}$ values found in this paper ranged from 6.46 to 7.11 . An increase in $\mathrm{pH}$ was observed, regardless of the cooking treatment. These data were similar to those found by Oetterer (2003) for Perna perna mussels collected in Ubatuba, which, according to the author, ranged from 5.8 to 6.9 in fresh mussels.

\subsection{Yield}

The values obtained for the yield of the edible part and of the total weight of mussels submitted to different thermal treatments are presented in Figure 3.

The yield determination was carried out with the objective of verifying possible losses in mussel yield due to the cooking period. Two forms of determination were adopted: one emphasizing the total weight and the other considering only the edible part of the mussels.
The yield varied from 45.72 to $69.24 \%$ with the treatment. Higher yields were obtained with shorter cooking times. Although differences were observed, all treatments had a high total weight yield, according to the Commercial Condition Index proposed by Gomes, Marenzi and Manzoni (1998), in which average and maximum yields are respectively 21.64 and $40.32 \%$.

In studies carried out by Beirão (2002), yield values of about $11 \%$ were found for the ratio shell/meat. These values cannot be compared because the evaluation occurred using different methods, once the author evaluated only the tissue weight.

\subsection{Sensory Analysis}

Table 4 shows the differences in the sum of the ordering of each sample, being statistically evaluated by Friedman's test using data from Newell and MacFarlane's (1987) table.

The critical value for the significance level of 5\%, according to Newell and MacFairlane's (1987) table is 34.

The results obtained in this paper show that even with longer thermal treatment periods, sensory losses did not take place, and the best treatment in the panelists' opinion was the 10-minutes treatment in boiling water. The use of boiling water or steam did not influence the final product, resulting in goodquality products in both treatments.

In studies carried out by Cambero et al. (1998), who observed the effects of different cooking methods on the aromatic compounds of shrimp (Parapenaeus longirostris) broth, the best shrimp extract was obtained with the treatment at $55^{\circ} \mathrm{C}$ for 120 minutes and, the higher the temperature applied, the

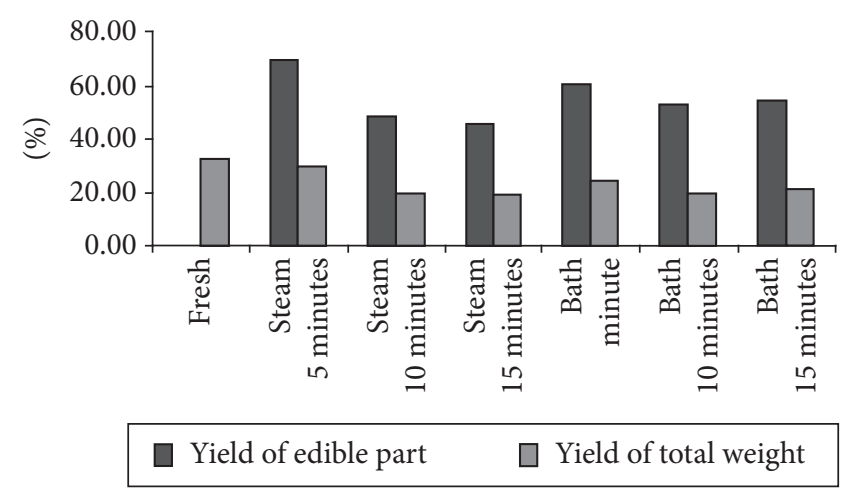

Figure 3. Yield of edible part and of total weight (\%) of mussels submitted to different thermal treatments.

Table 4. Differences in the sum of the ordering of each sample submitted to the ordering test.

\begin{tabular}{|c|c|c|c|c|}
\hline \multirow[t]{3}{*}{ Thermal treatments } & \multicolumn{4}{|c|}{ Samples } \\
\hline & \multicolumn{2}{|c|}{ Steam } & \multicolumn{2}{|c|}{ Water bath } \\
\hline & $\begin{array}{c}5 \\
\text { minutes }\end{array}$ & $\begin{array}{c}10 \\
\text { minutes }\end{array}$ & $\begin{array}{c}5 \\
\text { minutes }\end{array}$ & $\begin{array}{c}10 \\
\text { minutes }\end{array}$ \\
\hline Steam 5 minutes & - & 0 & 1 & 9 \\
\hline Steam 10 minutes & - & - & 1 & 9 \\
\hline Water bath 5 minutes & - & - & - & 10 \\
\hline Water bath 10 minutes & - & - & - & - \\
\hline
\end{tabular}


shorter the times needed to obtain the best extracts, such as, for example, $95^{\circ} \mathrm{C}$ for 15 and 30 minutes.

Antoniolli (1999), studying the shelf life of processed and refrigerated Perna Perna mussels, used different cooking times, ranging from 15 to 30 minutes, and observed that a 30 -minutes cooking of the mussels with a final temperature of $96^{\circ} \mathrm{C}$ resulted in the best sensory characteristics and improvement of the mussel shells removal process.

\section{Conclusions}

The present investigation allowed us to conclude that a microbial growth of $S$. aureus and B. cereus took place both in fresh and cooked mussels, along the 10 hours of observation. The mussels kept at room temperature $\left(25 \pm 1^{\circ} \mathrm{C}\right)$ had a higher growth compared to those stored under refrigeration $\left(7 \pm 1{ }^{\circ} \mathrm{C}\right)$, a fact that emphasizes the need of refrigeration of artisan mussels.

All thermal treatments applied were efficient, reducing both microorganisms by at least 2 logarithmic cycles. The boiling water bath treatments were more efficient than the steam treatments.

In the physical-chemical and sensory analysis, variations were not observed among any of the thermal treatments applied. The yield was higher for shorter periods of exposure to heat, and higher in water bath treatments than in steam treatments.

\section{References}

ACAQ. Associação Catarinense de Aqüicultura. Valores nutricionais do mexilhão Perna perna e da ostra Crassostrea gigas. Available at: $<$ http://www.acaq.org.br/valores_nutricionais.htm $>$. Access on: 24 Oct. 2005.

ACKMAN, R. G. Composición y valor nutritivo de los lipídios del pescado y del marisco. In: RUITER, A. El pescado y los productos derivados de la pesca: composición, propriedades nutritivas y estabilidad. Zaragoza: Acribia, 1999. cap. 4, p. 81-121.

AMA, A. A.; HAMDY, M. K.; TOLEDO, R. T. Effects of heating, $\mathrm{pH}$ and thermoradiation on inactivation of $V$. vulnificus. Food Microbiology, Netherlands, v. 11, n. 1, p. 215-227, 1994.

ANTONiOlLI, M. A. Vida útil do mexilhão Perna perna (L.) processado e mantido sob refrigeração.1999. 99f. Dissertação (Mestrado em Ciência dos Alimentos) - Departamento de Ciência e Tecnologia de Alimentos, Centro de Ciências Agrárias, Universidade Federal de Santa Catarina. Florianópolis, 1999.

A.O.A.C. Association of Official Analytical Chemists. Official methods of analysis. 16 ed. Washington: A.O.A.C., 1995. v. 2. p. 1250.

AYULO, A. M. R.; MACHADO, R. A.; SCUSSEL, V. M. Enterotoxigenic Escherichia coli and Staphylococcus aureus in fish and seafood from the southern region of Brazil. International Journal of Food Microbiology. Netherlands, v. 24, n. 1-2, p. 171-178, 1994.

BEIRÃO, H. et al. Processamento e industrialização de moluscos. In: SEMINÁRIO E WORKSHOP TECNOLOGIAS PARA APROVEITAMENTO INTEGRAL DO PESCADO,1., 2000. Campinas. Anais... Seminário e Workshop Tecnologias para Aproveitamento Integral do Pescado. Campinas: Centro de Tecnologia de Carnes, ITAL, 2000. p. 38-84.
BEIRÃO, L. H. Industrialização de mariscos e ostras. In: ENCONTRO DO AGRONEGÓCIO DA PESCA E AQUICULTURA, 1. 2002. Comunicação pessoal.

BINDU, J. et al. Effect of vacuum packaging on the shelf life of fried mussel, Perna viridis (Linnaeus) in flexible packaging material. Fishery Technology, India, v. 39, n. 2, p. 137-141, 2002.

BORGHETTI, J. R.; OSTRENSKY, A. A cadeia produtiva da aqüicultura brasileira. In: VALENTI, W. C. et al. Aqüicultura no Brasil, Brasília: CNPq, 2000. p. 107-142.

CAMBERO, M. I., et al. Effect of cooking conditions on the flavour compounds and composition of shrimp (Parapenaeus longirostris) broth. Zeitschrift für Lebensmitteluntersuchung und Forschun, Hamburgo, v. 206, n. 5, p. 311-322, 1998.

CHAI, T. et al. Effect of heat processing on quality of pasteurized oysters. Journal of Food Science, Chicago, n. 56, v. 5, p. 1294-1298, 1994.

FAO. El Estado de los recursos pesqueros: tendencias de la producción, aprovechamiento y comercio. Available at: <http://www.fao.org/ DOCREP/003/X8002S>. Access on: 20 May 2005.

FORSYTHE, S. J. Microbiologia da segurança alimentar. Porto Alegre: Artmed, 2002. 424 p.

FRANCO, G. V. E. Nutrição: texto básico e tabela de composição química de alimentos. 8 ed. São Paulo: Livraria Atheneu, 2004, p. 226.

GALVÃO, J. A. et al. Características físico-químicas e microbiológicas (Staphylococcus aureus e Bacillus cereus) da água e dos mexilhões cultivados na região de Ubatuba, SP. Ciências Agrotécnica, Lavras, v. 30, n. 6, p. 1124-1129, nov.dez.,2006.

GELLI, V. C. Aproveitamento de mexilhões: aspectos gerais MolluscaBivalvia. Fortaleza: LABOMAR, 1992. 64 p.(Monografia do curso de Especialização em Tecnologia de Produtos Pesqueiros. Departamento de Engenharia de Pesca, Universidade Federal do Ceará).

GELLI, V. C. et al. Caracterização da mitilicultura no Litoral Norte de São Paulo. In: SEMANA NACIONAL DE OCEANOGRAFIA, 11. 1998. Porto Alegre. Resumos. Porto Alegre: Editora Universitária, 1998. p. 37-40.

GOKOGLU, N.; YERLIKAYA, P.; CENGIZ, E. Effects of cooking methods on the proximate composition and mineral contents of rainbow trout (Oncorhynchus mykiss). Food Chemistry, Netherlands, v. 84, n. 1, p. 19-22, 2004.

GOMES, R. O.; MARENZI, A. W. C.; MANZONI, G. C. Utilização econômica do índice de condição do mexilhão Perna perna (L., 1758), no parque de mitilicultura na enseada de Armação do Itapocoroy, (26 $47^{\prime}$ S- $48^{\circ} 36^{\prime} \mathrm{W}$ ) Penha, SC, Brasil. In: SIMPÓSIO BRASILEIRO DE AQUICULTURA, 10. 1998. Florianópolis. Resumos. Florianópolis: Editora Universitária, 1998. p.119.

HAARD, N. F. Control of chemical composition and food quality attributes of cultured fish. Food Research International. Netherlands, v. 1, n. 25, p. 289-307, 1992.

JOHNSON, K. M.; NELSON, C. L.; BUSTA, F. F. Influence of temperature on germination and growth of spores of emetic and diarrheal strains of Bacillus cereus in a broth medium and in rice. Journal of Food Science, Chicago, v. 48, n. 1, p. 286-287, 1983.

JUNEIA, V. K.; MARMER, B. S.; EBLEN, B. S. Predictive model for the combined effect of temperature, $\mathrm{pH}$, sodium chloride, and sodium pyrophosphate on the heat resistance of Escherichia coli O157:H7. Journal of Food Safety, USA, v. 19, n. 2, p. 147-160, 1999.

KONGKACHUICHAI, R.; NAPATTHALUNG, P.; CHAROENSIRI, R. Heme and Nonheme Iron Content of Animal Products Commonly 
Consumed in Thailand Journal of Food Composition and Analysis, Netherlands, v. 15, n. 4, p. 389-398, 2002.

KOTROLA, J. S.; CONNER, D. E. Heat inactivation of Escherichia coli O157:H7 in turkey meat as affected by sodium chloride, sodium lactate, polyphosphate, and fat content. Journal of Food Protection, USA, v. 60, n. 8, p. 898-902, 1997.

LANCIOTTI, R. et al. Growth/no growth interfaces of Bacillus cereus, Staphylococcus aureus and Salmonella enteritidis in model systems based on water activity, $\mathrm{pH}$, temperature and ethanol concentration. Food Microbiology, Netherlands, v. 18, n. 6, p. 659-668, 2001.

MEAD, P. S. et al. Food related illness and death in the United States. Emerging Infectious Diseases, USA, v. 5, n. 5, p. 607-625, 1999.

NEWELL, G. J.; MACFARLANE, J. D. Expanded tables for multiple comparison procedures in the analysis of ranked data. Journal of Food Science, v. 52, n. 6, p. 1721-1725, 1987.

OETTERER, M. Relatório da $1^{\text {a }}$ fase do projeto de políticas públicas da FAPESP - Processo 01/12919 - 1.2003. Diagnóstico e intervenções emergentes para viabilizar a comercialização e o beneficiamento do pescado e derivados-mexilhões, no Litoral Norte de São Paulo. $85 \mathrm{p}$.

OLA, J. B.; OLADIPO, A. E. Storage life of croaker (Pseudotholitus senegalensis) in ice and ambient temperature. African Journal of Biomedical Research, África do Sul, v. 7, n. 1, p. 13-17, 2004

OSTRENSKY, A.; BORGHETTI, J. R.; PEDINI, M. Situação atual da aqüicultura brasileira e mundial. In: VALENTI, W.C et al. Aquicultura no Brasil. Brasília: CNPq, 2000. p. 355-381.

PAN, T. M. et al. Food-borne disease outbreaks due to bacteria in Taiwan, 1986 to 1995. Journal of Clinical Microbiology, Washington, v. 35, n. 5, p. 1260-1262, 1997.

PEDROSA, L. F. C.; COZZOLINO, S. M. F. Composição centesimal e de minerais de mariscos crus e cozidos da cidade de Natal RN. Ciência e Tecnologia de Alimentos, Campinas, v. 21, n. 2, p. 154-157, 2001.

PEREIRA, O. M. et al. Programa de desenvolvimento da criação ordenada de moluscos bivalves no Estado de São Paulo. Available at: <http://www.pesca.sp.gov.br/RelTec2.htm> Access on: 15 Nov. 2005.

PIGOTT, G. M.; TUCKER, B. Seafood: effects of technology on nutrition. New York: Marcel Dekker, 1990. 362 p.

RAWLES, D. et al. Listeria monocytogenes occurrence and growth at refrigeration temperatures in fresh blue crab (Callinectes sapidus) meat. Journal of Food Protection, USA, v. 58, n. 11, p. 1219-1221, 1995.
REILY, L. A.; HACKNEY, C. R. Survival of Vibrio cholerae during cold storage in artificially contaminated seafoods. Journal of Food Science, Chicago, v. 50, n. 3, p. 838-839, 1985.

RODRIGUES, P. F. Caracterização sanitária de áreas de criação de moluscos bivalvos do litoral norte do Estado de São Paulo. 1999. 66 f. Dissertação (Mestrado em Ciência) - Instituto de Biociências, Universidade de São Paulo, São Paulo, 1999.

RODRIGUES-ARIZA, A., et al. Metal, mutagenicity, and biochemical studies on bivalves mollusks from Spanish coasts. Environmental and Molecular Mutagenesis, USA, v. 19, n. 2, p.112-124, 1992.

SAS Institute. SAS user's guide: statistics (software). Version 8.0. Cary: SAS, 1999.

SCHRAMM, M. A. Caracterização e aproveitamento de mexilhões Perna perna (Linné, 1758). Porto Alegre: FURG, 1993. 54 p. (Monografia de Bacharelado). Faculdade de Engenharia de Alimentos Universidade Federal do Rio Grande do Sul.

SILVA, J. A. Tópicos da tecnologia dos alimentos. São Paulo: Livraria Varela, 2000. 227 p.

SKIPNES, D. et al. Heat transfer in vacuum packed mussels (Mytilus edulis) during thermal processing. Journal of Aquatic Food Product Technology, Canadá, v. 11, n. 3-4, p. 5-21. 2002.

SKONBERG, D. I.; PERKINS, B. L. Nutrient composition of green crab (Carcinus maenus) leg meat and claw meat. Food Chemistry, Netherlands, v. 77, n. 4, p. 401-404, 2002.

STREIT, D. P. et al. Perspectivas atuais da aquicultura marinha no Brasil. Revista Urutaguá, Maringá, v. 1, n. 4, p. 80-82, 2002.

SUBASINGHE, R. P. et al. Aquaculture in the Third Millennium. In: Technical Proceedins of the Conference on Aquaculture in The Third Millenium. Bangkok: NACA; Rome: FAO, 2001. 471 p.

TAVARES, M. et al. Métodos sensoriais, físicos e químicos para análise de pescado. In: Seminário sobre Controle de Qualidade na Indústria de Pescado, 1., 1988. Santos. Anais do Seminário sobre Controle de Qualidade na Indústria de Pescado. São Paulo: Instituto de Pesca, 1998. p. 117-134.

VANDERZANT, C.; SPLITTSTOESSER, D. F. Compendium of methods for the microbiological examination of foods. 3.ed. Washington: American Public Health Association, 1992. cap. 25, $1219 \mathrm{p}$

WOOD, P. C. Manual de higiene de los mariscos. Zaragoza: Acribia, 1979. 79 p. 